\title{
Pelatihan Internet Sebagai Media Informasi dan Komunikasi Untuk Santri Pada Pondok Pesantren Daarul Hasanah Bogor
}

\author{
Roy Irawan ${ }^{1}$, Darma Wijaya ${ }^{2}$, Indra Prana ${ }^{3}$, Intan Kusuma Dewi ${ }^{4}$ \\ ${ }^{1234}$ Universitas Bina Sarana Informatika \\ Jl. Kramat Raya No 98, Senen, Jakarta Pusat, Indonesia
}

e-mail: ${ }^{1}$ roy.ryi@bsi.ac.id, ${ }^{2}$ darma.dwa@bsi.ac.id, ${ }^{3}$ indra.ipa@bsi.ac.id, ${ }^{4}$ intan.ikd@bsi.ac.id

\begin{abstract}
Abstrak
Kegiatan pengabdian masyarakat ini mengambil tema pelatihan internet sebagai media informasi dan komunikasi untuk santri pada Pondok Pesantren Daarul Hasanah Bogor, pelaksanaan dilakukan secara virtual melalui Zoom Meating dengan peserta santri di Pondok Pesantren Darul Hasanah yang berlokasi di jl abdul fatah , kampung Babagan Rt 22/5, desa cinangneng Kec Tenjolaya Bogor Barat .Materi yang disampaikan meliputi penggunaan internet sebagai media informasi dan pengetahuan . permasalahan prioritas yang ada pada mitra Pondok Pesantren Daarul Hasanah meliputi Sulitnya mengakses jaringan internet untuk pendidkan pesantren dan untuk mendapatkan informasi pengetahuan dan komunikasi, Sarana dan prasarana pendukung yang terbatas di pondok pesantren, ketersediaan listrik dalam proses pembelajaran santri di pondok pesantren, Pengetahuan teknis ustadz tentang penggunaan teknologi informasi dan komunikasi yang terbatas. Metode pelaksanaan yang ditempuh untuk mengatasi permasalahan penggunaan internet pada pondok pesantren darul hasanah yaitu pendidikan masyarakat dengan melakukan observasi dan pemberian koesioner.Di akhir kegiatan pengabdian masyarakat tersebut kami melakukan evaluasi dengan cara memberikan koesioner dengan responden kurang lebih 20 orang untuk melihat presentase tingkat kepuasan peserta ( santri dan ustadz ) selama mengikuti kegiatan pengabdian masyarakat serta untuk mengukur secara kuantitatif presentase pengaruh dan dampak yang ditimbulkan setelah selesai mengikuti pelaksanaan kegiatan tersebut.Setelah proses evaluasi, kami akan melihat reaksi dan responsif dari peserta serta selalu memonitoring proses pembelajaran pada pondok pesantren darul hasanah. target luaran dari kegiatan pengabdian masyarakat ini berupa Pengetahuannya meningkat, Keterampilannya meningkat, pelayanannya meningkat.
\end{abstract}

Kata Kunci : pelatihan internet, media informasi, komunikasi

\section{Abstract}

This community service activity took the theme of internet training as a medium of information and communication for students at the Daarul Hasanah Islamic Boarding School, Bogor, the implementation was carried out virtually through Zoom Meating with santri participants at the Darul Hasanah Islamic Boarding School located on Jl Abdul Fatah, Babagan Village Rt 22/5, Cinangneng Village, Tenjolaya District, West Bogor. The material presented includes the use of the internet as a medium of information and knowledge. Priority problems that exist in Daarul Hasanah Islamic Boarding School partners include the difficulty of accessing the internet network for pesantren education and to obtain information, knowledge and communication, limited supporting facilities and infrastructure in Islamic boarding schools, availability of electricity in the learning process of students in Islamic boarding schools, technical knowledge of Ustadz about limited use of information and 
communication technology. The implementation method adopted to overcome the problem of using the internet at the Darul Hasanah Islamic boarding school is public education by observing and giving questionnaires to responden 20 persons santri and ustadz, during community service activities and to quantitatively measure the percentage of influence and impact after completing the implementation of these activities. After the evaluation process, we will see the reactions and responsiveness of participants and always monitor the learning process at the Darul Hasanah Islamic Boarding School. The output target of this community service activity is in the form of increasing knowledge, increasing skills, increasing service.

Keywords: internet training, information media, communication

\section{Pendahuluan}

Dampak dari pandemi Covid 19 begitu besar dirasakan oleh seluruh lapisan masyarakat diberbagai bidang. Peraturan pemerintah dalam menerapkan protokol kesehatan yaitu menjaga jarak menyebabkan terputusnya informasi ilmu pengetahuan terutama dibidang pendidikan. Dunia pendidikan sebagai pusat berkembangnya Ilmu Pengetahuan dan Teknologi (IPTEK) dan penghasil Sumber Daya Manusia (SDM) yang berkualitas tentulah sangat menyambut baik kehadiran teknologi informasi yang semakin canggih (S.Huzni, 2008), Teknologi informasi saat ini juga sudah menjadi sebuah kebutuhan yang sangat berarti diberbagai sendi kehidupan (Nugroho, 2006). Internet sebagai media pembelajaran mulai diterapkan pada dunia pendidikan. Peserta didik diajarkan mengenai pengoperasian internet, tujuannya adalah agar peserta didik mengenal dunianya, dunia yang tidak berhenti mengalami perkembangan teknologi (Irawan, 2017). Tidak hanya kalangan tertentu yang dapat mengakses internet tetapi sudah semua kalangan dari anak, remaja dan orang dewasa semua telah menggunakannya. Internet hadir tidak hanya bersama dampak positif, namun juga banyak dampak negatif (Hidayanto \& Zidni Ilmi, 2015). Namun peranan internet sangat berarti dalam proses belajar pada masa pandemi. Apalagi Era penggunaan internet saat ini sudah masuk semua batas usia dan daerah. Dengan semakin mudahnya penggunaan smart phone tentunya juga semakin mempermudah dalam melakukan aktifitas dengan menggunakan fasilitas internet (Sholeh \& Basuki, 2018) . serta harga yang semakin murah yang ditawarkan oleh internet service provider ataupun operator telepon seluler mendukung kebijakan pemerintah dalam bidang teknologi informasi untuk menyediakan sarana informasi yang seluas-luasnya kepada masyarakat.

Perguruan Tinggi juga diharapkan oleh pemerintah untuk dapat meng-edukasi masyarakat dalam menggunakan teknologi informasi tersebut. Melalui Tri Darma Perguruan Tinggi dalam bidang Pengabdian Masyarakat, kami selaku dosen yang menpunyai kewajiban untuk melakukan Tri Darma bidang Pengabdian Masyarakat menyelenggarakan Pengabdian kepada Masyarakat dengan mengambil Tema penggunaan internet sebagai media informasi dan komunikasi untuk santri pada Pondok Pesantren Daarul Hasanah Bogor. Dengan informasi yang disampaikan santri melalui internet, maka santri akan dengan mudah menerima informasi dan berinteraksi dengan media internet.

Kegiatan ini dilaksanakan di secara virtual melalui Zoom Meating dengan peserta santri di Pondok Pesantren Darul Hasanah yang berlokasi di jl abdul fatah, kampung Babagan Rt 22/5, desa cinangneng Kec Tenjolaya Bogor Barat .Materi yang disampaikan meliputi penggunaan internet sebagai media informasi dan pengetahuan. kegiatan ini merupakan pertama kali kami bekerjasama dengan kalangan santri dilingkungan Pondok Pesantren Darul Hasanah. Banyak santri yang mengeluhkan tentang kesulitan dalam mengakses internet dikarenakan jaringan, kurang pahamnya dalam penggunaan teknologi informasi dan komunikasi, kurangnya sarana dan prasarana pendukung yang terbatas di pondok pesantren, ketersediaan listrik dalam proses pembelajaran santri di pondok pesantren serta pengetahuan teknis ustadz tentang penggunaan 
teknologi informasi dan komunikasi yang terbatas, santri yang ada pada Pondok Pesantren Darul Hasanah memiliki bekal pendidikan yang beragam Dan dengan menggunakan internet di harap santri dapat meningkatkan pengetahuan tentang agama islam lewat situs situs agama islam

Tujuan dari pelatihan pengabdian masyarakat ini yaitu berupaya untuk meningkatkan kemampuan ilmu keagamaan islam dengan menambah keahlian dalam penggunaan internet untuk mencari informasi sebanyak banyaknya tentang agama islam serta untuk sarana dakwah melalui internet.

\section{Metode}

\section{Solusi yang ditawarkan}

Pemecahan masalah dilakukan berdasarkan rumusan masalah yang telah diungkapkan dengan memberikan pemahaman kepada para santri dan ustadz pada pondok pesantren daarul hasanah tentang penggunaan internet sebagai sarana komunikasi serta informasi maka dari itu metode pelaksanaan yang ditempuh untuk mengatasi permasalahan penggunaan internet pada pondok pesantren darul hasanah yaitu

\section{a. Pemetaan ( mapping )}

Memetakan permasalahan apa yang dihadapi dan solusi yang dibutuhkan. Hasil pemetaan diharapkan bisa memberikan gambaran keterampilan memecahkan masalah (Kurniawati et al., 2019) yang dibutuhkan oleh para santri dan ustadz di pondok pesantren daarul hasanah bogor.

\section{b. Wawancara}

Wawancara merupakan suatu teknik pengumpulan data secara langsung, saling bertukar pikiran dan informasi mengenai permasalahan yang di tentukan (Imtihan \& Basri, 2019).

Wawancara dilakukan secara langsung kepada para santri dan ustadz di pondok pesantren daarul hasanah bogor untuk menentukan materi dan gambaran pemaparan tentang penggunaan internet sebagai sarana komunikasi dan informasi.

\section{c. Metode penyelesaian masalah}

Pelatihan adalah adanya serangkaian aktivitas yang dirancang untuk meningkatkan keahlian-keahlian, pengetahuan, pengalaman ataupun perubahan sikap seseorang, Dengan melakukan pelatihan kepada para santri dan ustadz di pondok pesantren daarul hasanah bogor diharapkan dapat menambah wawasan tentang pentingnya penggunaan internet sebagai sarana komunikasi dan informasi dengan tetap memperhatikan protokol kesehatan.

\section{d. Implementasi dan pelaksanaan}

Pelaksanaan acara dilakukan dengan menggunakan:

\section{1) Metode Ceramah}

Metode ceramah merupakan proses penyaluran informasi satu arah dari penyuluh kepada peserta atau sasaran penyuluhan, dimana metode ini cocok digunakan untuk sasaran dengan pendidikan tinggi maupun rendah dan mudah dalam perencaanaannya dan efisien waktu (Ningtyas et al., 2018). Memberikan pemahaman dan motivasi serta memberikan gambaran penerapan tentang penggunaan internet sebagai sarana komunikasi dan informasi

\section{2) Metode Tutorial}

Tutorial merupakan metode alternatif yaitu bacaan, demonstrasi, pengalaman yang membutuhkan respon serta ada ujian (Sembiring et al., 2018). Peserta dipandu secara langsung menggunakan aplikasi Zoom Cloud Meeting berdasarkan materi dan praktikum yang dilakukan.

\section{3) Metode Diskusi}


Diskusi merupakan suatu metode atau cara mengajar dengan cara memecahkan masalah yang dihadapi, baik atau lebih, dimana setiap peserta diskusi berhak mengajukan argumentasinya untuk memperkuat pendapatnya (Gustian et al., 2019). Melakukan diskusi tentang penerapan penggunaan internet sebagai sarana komunikasi dan informasi pada sesi tanya jawab.

\section{Pelaksanaan Kegiatan}

Pengabdian masyarakat ini dilakukan melalui Zoom Meeting dengan kepada para santri dan ustadz di pondok pesantren daarul hasanah bogor

\section{Target Luaran}

\section{a. Target pengabdian masyarakat}

Terlaksananya kegiatan pengabdian masyarakat tentang penggunaan internet sebagai sarana komunikasi dan informasi di pondok pesantren daarul hasanah bogor.

\section{b. Luaran pengabdian masyarakat}

Terlaksananya kegiatan belajar mengajar yang efektif pada pesantren daarul hasanah bogor yang yang diikuti oleh para santri serta para ustadz tanpa khawatir bertemu langsung mengingat pandemi Covid-19 dan tetap memperhatikan protokol kesehatan.

\section{Hasil dan Pembahasan}

Kegiatan Pengabdian Masyarakat yang dilaksanakan pada hari minggu, tanggal 21 Maret 2021 dengan menggunakan fasilitas Zoom Cloud Meeting, diikuti sebanyak 20 orang peserta yang terdiri dari para santri serta para ustadz pesantren daarul hasanah bogor. Materi kegiatan Pengabdian Masyarakat adalah pelatihan internet sebagai media informasi dan komunikasi untuk santri pada Pondok Pesantren Daarul Hasanah Bogor. Pelaksanaan pelatihan dilakukan secara online, dengan membahas penggunaan internet untuk proses belajar mengajar di pondok pesantren daarul hasanah dapat berjalan dengan baik dan efektif.

\section{Tahapan pelaksanaan pelatihan dilakukan sebagai berikut:}

1. Peserta pelatihan mempersiapkan Laptop yang terinstal Aplikasi Zoom Cloud Meeting.

2. Peserta pelatihan mengakses Link User dan Password Zoom Cloud Meeting.

3. Peserta mengikuti acara pelatihan dengan mengikuti penjelasan materi penggunaan internet sebagai media informasi dan komunikasi untuk santri pada Pondok Pesantren Daarul Hasanah Bogor khususnya disaat pandemi untuk mencegah penularan virus Covid-19.

4. Peserta berlatih mempraktikan dan mengerjakan sebuah contoh penggunaan internet seperti membuat registrasi email, membuat blog dan pencarian informasi menggunakan google dan search engine lainnya. Di mana proses pelatihan meliputi memberikan pengertian tentang internet dilanjutkan bagaimana membuat account gmail, serta bagaimana pencarian informasi lewat google seperti pencarian tinjauan buku buku agama di google book serta pencarian web site yang berkaitan dengan keagamaan islam dan terakhir membuat blog dari situs blogspot. 


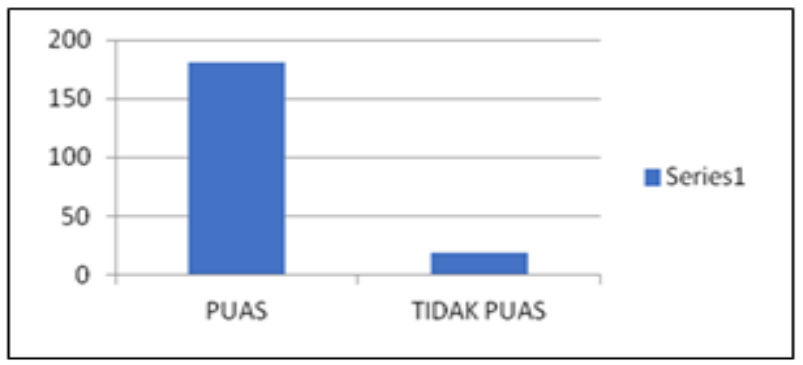

Gambar 1. Diagram Tingkat Kepuasan Peserta Dalam Kegiatan Pengadian Masyarakat

Dari gambar diagram 1 maka dari 10 pernyataan yang diberikan untuk 20 responden santri dan santriwati pondok pesantren Daarul Hasanah diketahui tingkat kepuasan peserta selama mengikuti pelatihan sebesar 181 atau 90,5\% dan tingkat ketidak puasan sebesar 19 atau 9,5 $\%$.

Setelah mengikuti pelatihan santri dapat meningkatkan kemampuan dan pengetahuannya dalam penggunaan internet untuk proses belajar mengajar, dapat menambah pengetahuan teknis serta keterampilan teknis dalam pemakaian teknologi informasi dan komunikasi serta mengetahui tingkat penggunaan dan pemakaian alat komputerisasi dalam proses pembelajaran.

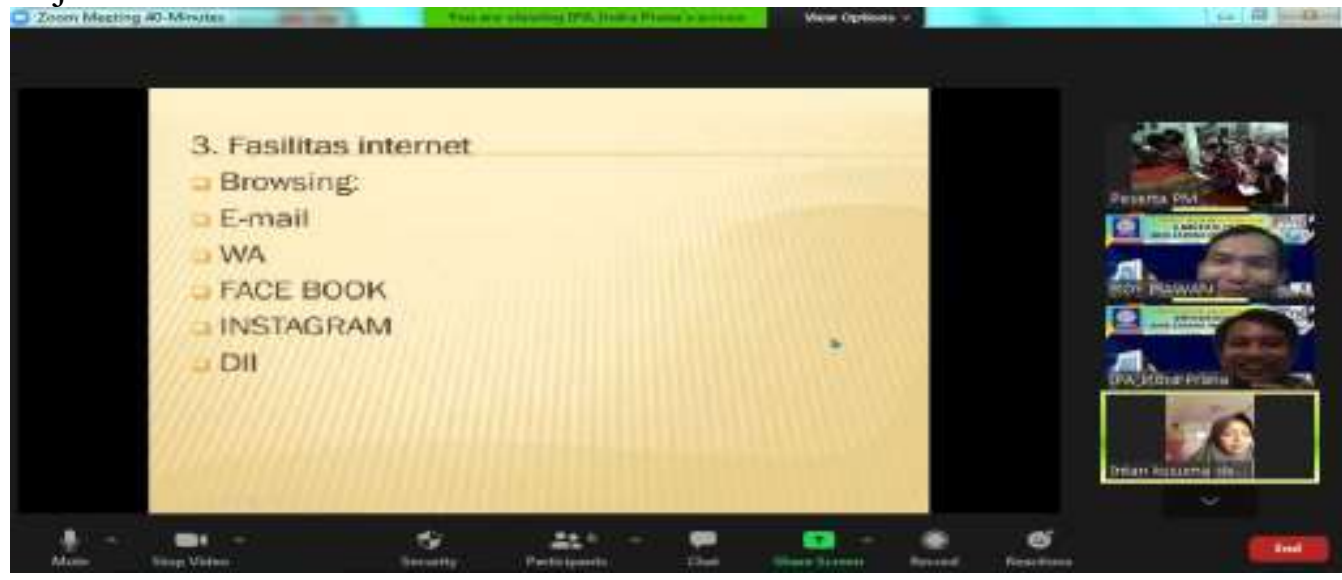

Gambar 2

Penyampaian Materi Oleh Tutor Tentang Fasilitas Internet

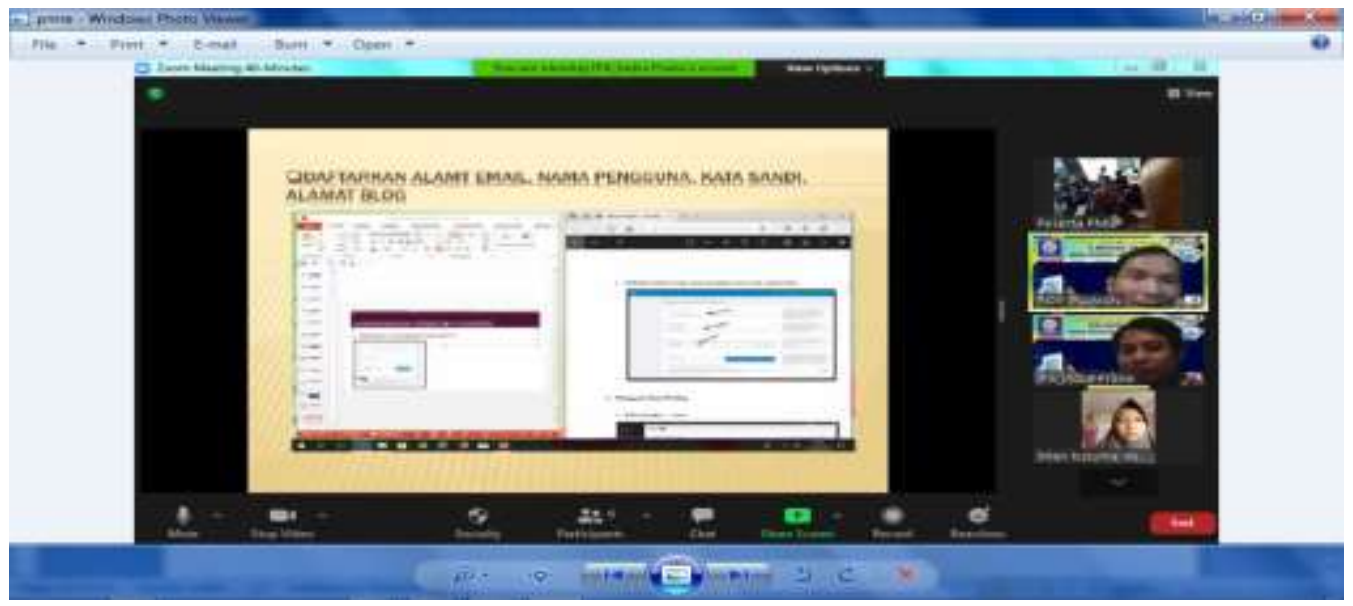

Gambar 3

Penyampaian materi oleh tutor tentang pembuatan blog 
5. peserta berlatih mengunakan fasilitas internet seperti email, facebook, instagram, browsing di google dan bagaimana membuat blog sehingga mereka dapat menggunakan menu menu yang ada pada aplikasi internet tersebut dengan baik.

\section{Kesimpulan}

Dalam pengabdian masyarakat yang kami laksanakan pada tanggal 21 maret 2021 di pondok pesantren Daarul Hasanah maka kami menarik kesimpulan sebagai berikut : Kegiatan pengabdian masyarakat ini mengambil tema pelatihan internet sebagai media informasi dan komunikasi untuk santri pada Pondok Pesantren Daarul Hasanah Bogor, pelaksanaan dilakukan secara virtual melalui Zoom Meating dengan peserta santri di Pondok Pesantren Darul Hasanah yang berlokasi di jl abdul fatah, kampung Babagan Rt 22/5, desa cinangneng Kec Tenjolaya Bogor Barat .Materi yang disampaikan meliputi penggunaan internet sebagai media informasi dan pengetahuan. Metode pelaksanaan yang ditempuh dalam kegiatan pengabdian masyarakat dengan tema penggunaan internet pada pondok pesantren darul hasanah yaitu dengan melakukan observasi dan pemberian koesioner kepada para ustadz serta santri untuk menentukan presentase tingkat kesulitan dan tingkat kemudahan penggunaan internet serta dampak pengaruh yang ditimbulkan dari penggunaan internet untuk proses pembelajaran dipondok pesantren darul hasanah sebelum dan sesudah pelaksanaan kegiatan. Di akhir kegiatan pengabdian masyarakat tersebut kami melakukan evaluasi dengan cara memberikan koesioner dengan responden kurang lebih 20 orang untuk melihat presentase tingkat kepuasan peserta ( santri dan ustadz) selama mengikuti kegiatan pengabdian masyarakat serta untuk mengukur secara kuantitatif presentase pengaruh dan dampak yang ditimbulkan setelah selesai mengikuti pelaksanaan kegiatan tersebut. Target luaran dari kegiatan pengabdian masyarakat ini berupa Pengetahuannya meningkat, Keterampilannya meningkat, pelayanannya meningkat sedangkan Luaran publikasi pengabdian kepada masyarakat bisa berupa artikel /pressrelease pada media masa cetak atau elektronik

\section{Daftar Pustaka}

Gustian, H., Jaenudin, J., Eosina, P., Teknik, J., Teknik, F., Ibn, U., Bogor, K., Kh, J., Km2, S. I., \& Bogor, K. (2019). Sistem Informasi Forum Diskusi Layanan Mandiri Online Warga Rw09 Kelurahan Karadenan Kecamatan Cibinong Kabupaten Bogor. IKRA-ITH INFORMATIKA : Jurnal Komputer dan Informatika, 3(1), 46-54. https://journals.upiyai.ac.id/index.php/ikraith-informatika/article/view/297

Hidayanto, F., \& Zidni Ilmi, M. (2015). Pentingnya internet sehat. Jurnal Inovasi dan Kewirausahaan, 4(1), 21-24.

Imtihan, K., \& Basri, M. H. (2019). Sistem Informasi Pembuatan Manifest Muatan Kapal

Berbasis Dekstop Dan Android. Jurnal Manajemen Informatika dan Sistem Informasi, 2(2), 69. https://doi.org/10.36595/misi.v2i2.106

Irawan, R. (2017). Analisa Penggunaan Internet Terhadap Perkembangan Proses Belajar

Siswa (Studi kasus: siswa/siswi SMP dan SMU pada daerah sepatan tangerang selatan).

Widya Cipta: Jurnal Sekretari dan Manajemen, 1(2), 186-192.

Kurniawati, M., Sajidan, \& Ramli, M. (2019). Analisis Keterampilan Memecahkan Masalah Siswa SMA. Proceeding Biology Education Conference, 16(1), 75-78.

Ningtyas, I., Handayani, D., \& Kusumastuty, I. (2018). Pengetahuan Nutrition Facts dan 
Pemilihan Makanan Kemasan Mahasiswa Obesitas antara Metode Edukasi Personal dan Ceramah. Amerta Nutrition, 2(3), 271-282.

Nugroho, A. (2006). e-Commerce Memahami Perdagangan Modern di Dunia Maya. In Informatika.

S.Huzni. (2008). Pemanfaatan Media Internet Ssebagai Sumber Beajar. jurnal Iqro, 2, 72-83.

Sembiring, E. B., Wahyuni, D., \& Anurogo, W. (2018). Multimedia Interaktif Pengenalan Hewan Dan Tumbuhan Langka Menggunakan Model Tutorial. Journal Of Digital Education, Communication, And Arts (DECA), 1(2), 103-112. https://doi.org/10.30871/deca.v1i2.839

Sholeh, M., \& Basuki, U. (2018). Pemahaman Remaja Masjid Al Aman Kersen Bantul Pada Pengelolaan Media Sosial Secara Sehat Dan Cerdas. Jurnal Pengabdian Masyarakat Progresif Humanis Brainstorming, 1(2), 111-118.

https://doi.org/10.30591/japhb.v1i2.957 